\title{
Effect of fermented Hovenia dulcis Thunb fruit water extract on biomarker for liver injury and body weight changes in rats given oral administration of ethanol
}

\author{
Ji-Young Choi ${ }^{1}$, Jun-Han Kim ${ }^{2}$, Gho Kim ${ }^{3}$, Choon-Kyung Kim ${ }^{4}$, Myung-Sook Choi ${ }^{1}$ * \\ ${ }^{1}$ Department of Food Science and Nutrition, Kyungpook National University, Daegu 702-701, Korea \\ ${ }^{2}$ Bio Health Convergence center, Daegu Technopark, Daegu 704-801, Korea \\ ${ }^{3}$ Department of Psychology, Kyungpook National University, Daegu 702-701, Korea \\ ${ }^{4}$ Department of Child and Family Studies, Kyungpook National University, Daegu 702-701, Korea
}

\section{헛개열매추출액발효물이 흰쥐의 에탄올 경구투여에 의한 간손상 지표와 체중 감량 완화에 미치는 영향}

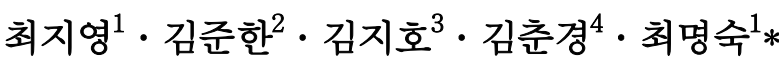 \\ ${ }^{1}$ 경북대학교 식품영양학과, ${ }^{2}$ (재)대구테크노파크 바이오헬스융합센터, ${ }^{3}$ 경북대학교 심리학과, \\ ${ }^{4}$ 경북대학교 아동가족학과
}

\begin{abstract}
This study was performed to investigate the effect of femented Hovenia dulcis Thunb fnit water extract on biomarkers for acute (a) ethanol-induced hangover and chronic (c) ethanol-induced liver injury in rats. For acute ethanol-induced hangover, the rats were administered distilled water (D.W., $10 \mathrm{~mL} / \mathrm{kg}$ body wt.), Hovenia dulcis Thunb fruit water extract (HWE, $400 \mathrm{mg} / 10 \mathrm{~mL} / \mathrm{kg}$ body wt.) and fermented HWE (FHWE, $400 \mathrm{mg} / 10 \mathrm{~mL} / \mathrm{kg} \mathrm{body} \mathrm{wt.),} \mathrm{respectively,}$ before $40 \%$ ethanol $(5 \mathrm{~g} / \mathrm{kg}$ body wt.) was administered. For chronic ethanol-induced liver injury, the rats were randomly divided into the normal control (cNC), ethanol (cET), cET-HWE and cET-FHWE groups. The cNC and cET groups were administered D.W. (10 mL/kg body wt.) before $40 \%$ alcohol $(5 \mathrm{~g} / \mathrm{kg}$ body wt.) was administrered for 21 days. The cET-HWE and cET-FHWE groups were administered HWE $(400 \mathrm{mg} / 10 \mathrm{~mL} / \mathrm{kg}$ body wt. $)$ and FHWE (400 mg/10 mL/kg body wt.), respectively before $40 \%$ ethanol (5 g/kg body wt.) administration for 21 days. For acute ethanol-induced hangover, the serum alcohol and acetaldehyde concentrations were more significantly reduced in the aHWE and aFHWE groups than in the aET group. Moreover, the effect of FHWE was greater than that of HWE. For chronic ethanol-induced liver injury, the serum ethanol, acetaldehyde, $\gamma$-glutamyl transpeptidase $(\gamma$-GTP) levels and the hepatic lipids concentration more significantly dropped in the cET-HWE and cET-FHWE groups than in the cET group. The FHWE administration showed faster recovery of the senum glucose concentration than in the cET and cET-HWE groups. The body weight reduction tended to normalize in the cET-HWE and cET-FHWE groups, which is ideal for chronic ethanol administration. These results suggest that FHWE has a protective effect against ethanol-induced liver damage, as evidenced by its ability to lower the senum ethanol and acetaldehyde concentrations after alcohol administration, and by its ability to decrease the level of $\gamma$-GTP and hepatic lipids. FHWE also elevated senum glucose concentration. Therefore, FHWE is effective in reducing ethanol-induced hangover and can play a beneficial role in the treatment of ethanol-induced liver damage as well as body weight reduction.
\end{abstract}

Key words : Hovenia dulcis Thunb fruit, Ferment, alcohol, acetaldehyde, liver

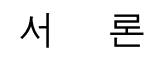

*Corresponding author. E-mail : mschoi@knu.ac.kr

Phone : 82-53-950-6232 Fax : 82-53-958-1230
음주는 전 세계적으로 만연한 생활습관으로 적절한 알코 올 섭취는 사교 및 건강증진에 도움을 주어 삶을 윤택하게 할 수 있지만 과음은 숙취로 인한 오심, 구토, 갈증, 두통 및 근육통 등의 증상을 유발하여 일상생활에 장애를 초래한 다. 또한 만성적인 알코올 섭취는 체내 영양소 흡수나 대사 
과정을 저해하여 영양결핍을 일으키며 알코올성 지방간, 간염, 간경변 등의 간질환과(1), 암(2,3), 당뇨(4,5), 심혈관계 질환(6-9), 신경정신장애 $(10,11)$ 등을 초래하여 막대한 사회 경제적 손실을 발생시킨다. 뿐만 아니라, 만성적인 알코올 대사는 저혈당과 저체중을 유도하여 에너지 대사에 불균형 을 초래한다.

알코올은 간에서 알코올분해효소(alcoholic dehydrogenase, $\mathrm{ADH}$ ) pathway, microsomal ethanol oxydizing system (MEOS), catalase pathway 등 3가지 경로에 의해 대사된다. 조직의 알코올 농도가 낮을 때는 $\mathrm{ADH}$ 체계, 알코올 농도가 높을 때는 $\mathrm{MEOS}$ 체계가 주로 알코올 대사에 관여하여 알코 올이 아세트알데하이드(acetaldehyde)를 거쳐 아세테이트 (acetate)로 산화된다. 아세트알데하이드는 숙취(hangover) 의 원인 물질로 체내 농도가 높을 때는 간세포에 잔류하게 되어 미토콘드리아의 기능 저해, 알데하이드분해효소 (aldehyde dehydrogenase, $\mathrm{ALDH}$ ) 활성 감소, 심장의 근육 단백질 합성 등을 일으키며 간 이외의 다른 조직, 특히 중추 신경계에 유해한 영향을 미치므로 아세트알데하이드의 신 속한 제거는 알코올 독성으로부터 간을 보호할 수 있는 것으로 사료된다(12). 또한 과잉의 알코올은 지질대사에도 영향을 미쳐 말초 지방조직의 지질분해 증가, 지방산의 과 잉생산, 지방산 산화 감소를 초래하여 간세포에 triglyceride 가 축적되는 지방간을 유발한다(13). 따라서 알코올 섭취로 인한 숙취를 제거하고 간 손상을 억제할 수 있는 물질에 대한 관심은 지속적으로 증가하고 있으며 이에 대한 연구가 활발히 진행되고 있다.

헛개나무(Hovenia dulcis Thunb.)는 갈매나무과의 낙엽 교목으로 지구자 나무라고도 하며, 한의학에서는 알코올 해독작용과 함께 지방간, 간경화 등의 간 기능 개선 효능이 우수한 것으로 알려짐에 따라 알코올이나 사염화탄소로 유도한 간손상 동물모델에서 간독성을 억제하는 효과에 대한 연구가 많이 보고되고 있으며(15-23) 최근에는 헛개나 무열매의 간기능 개선 작용뿐만 아니라 streptozotocin 당뇨 모델에서의 항당뇨 효능(24) 및 항산화 작용(25) 등이 보고 되었다.

따라서 본 연구에서는 알코올 분해 및 간기능 개선 효과 가 우수한 것으로 보고된 헛개열매열수추출물의 발효 시료 에 대해 동물실험을 이용한 기능성을 비교하고자 흰쥐에 알코올을 투여한 후 간손상, 저혈당 및 체중조절 관련 바이 오마커를 상호 비교·검증하였다.

\section{재료 및 방법}

\section{시료 제조}

본 실험에 사용된 헛개나무열매는 경동시장에서 유통되 는 건조된 형태의 국내산 한약규격품을 원료로 이용하였
다. 헛개나무열매는 세척한 후 추출에 적합하도록 세절하 여 시료 $1000 \mathrm{~g}$ 당 10 배의 증류수를 가하여 $98^{\circ} \mathrm{C}$ 에서 2 시간 동안 추출하였고, 이를 2회 반복한 후 감압여과장치로 여과 하여 헛개열매열수추출물을 획득하였으며 추출수율은 $26.7 \%$ 였다. 헛개열매추출액발효물은 헛개열매열수추출 물에 Lactobacillus fermenturm NUC-C1 KCCM10929P와 Saccharomyces cereviseae를 각각 $0.3 \%$ 씩 접종하여 $30^{\circ} \mathrm{C}$ 에 서 7일간 발효하여 제조하였다. 헛개열매열수추출물, 헛개 열매추출액발효물은 동결 건조하여 분말화한 후 본 실험에 사용하였다.

\section{실험디자인}

급성 알코올 투여에 의한 숙취해소 효능검증

급성 알코올 투여에 의한 숙취해소 효능 검증을 위한 실험디자인은 다음과 같다. 오리엔트바이오로부터 Wistar 계 랫드(수컷, 6주령, 190 220 g)를 입수하여 2주일간 순화 시켰다. 순화기간동안 음용수와 사료(Purina Inc., Seongnam, Korea)는 자유롭게 섭취하도록 하였고, 사육실은 낮과 밤 주기 12 시간, 온도 $20 \sim 26^{\circ} \mathrm{C}$, 습도 $40 ~ 60 \%$ 의 환경으로 2 주 간 랫드를 적응시킨 후 알코올대조군(ET), 헛개열매군 (ET-HWE), 헛개열매발효군(ET-FHWE)으로 각 7마리씩 3 개 군으로 무작위로 나누어 실험을 진행하였다. 식이에 의 한 알코올 흡수와 분해의 차이를 없애기 위하여 랫드는 12 시간 금식시킨 후 알코올대조군(ET)은 증류수 $10 \mathrm{~mL} / \mathrm{kg}$ body wt.를 헛개열매군(ET-HWE)과 헛개열매발효군(ET -FHWE)은 헛개열매열수추출물과 헛개열매추출액발효물 을 각각 $400 \mathrm{mg} / 10 \mathrm{~mL} / \mathrm{kg}$ body wt. 씩 경구 투여하였고, 30 분 뒤에 $20 \%$ 알코올 $5 \mathrm{~g} / \mathrm{kg}$ body wt.을 세 개의 실험군에 경구 투여하였다. 알코올 투여 후 1 시간 및 3 시간 후에는 꼬리에서, 5 시간 후에는 심장에서 혈액을 채취하여 $3,000 \times \mathrm{g}$ 에서 20 분 동안 원심 분리하여 혈청을 분리하였다. 1 시간, 3 시간, 5시간에 채취된 혈청은 알코올, 아세트알데하이드 측정에 사용되었고, 5시간에 채취된 혈청은 alanine transaminase(ALT), aspartate transaminase(AST) 및 $\gamma$-glutamyl transpeptidase $(\gamma$-GTP) 농도 측정에 사용되었다.

\section{만성 알코올 투여에 의한 간기능 개선 효능검증}

만성적인 알코올 섭취로부터 헛개열매추출액발효물의 간기능 개선 효능 검증은 다음과 같이 진행하였다. 오리엔 트바이오로부터 입수한 Wistar계 랫드(수컷, 7주령, 210 $264 \mathrm{~g}$ )는 음용수와 사료(Purina Inc., Seongnam, Korea)를 자유롭게 섭취하도록 하였고, 사육실은 낮과 밤 주기 12 시간, 온도 $20 \sim 26^{\circ} \mathrm{C}$, 습도 $40 \sim 60 \%$ 의 환경으로 2 주간 적응 시킨 후 정상대조군 $(\mathrm{NC})$, 알코올대조군(ET), 헛개열매군 (ET-HWE), 헛개열매발효군(ET-FHWE)으로 7마리씩 4개 군으로 무작위로 나누어 3주간 사육하였다. 즉, 정상대조군 과 알코올대조군(ET)은 증류수 $10 \mathrm{~mL} / \mathrm{kg}$ body wt.를 경구 
투여하고, 30 분 뒤에 각각 증류수와 $40 \%$ 알코올 $5 \mathrm{~g} / \mathrm{kg}$ body wt.를 각각 3 주간 경구투여 하였다. 헛개열매군 (ET-HWE) 및 헛개열매발효군(ET-FHWE)은 각각의 시험 물질 $400 \mathrm{mg} / 10 \mathrm{~mL} / \mathrm{kg}$ body wt.를 경구 투여하였고, 30분 뒤에 $40 \%$ 알코올 $5 \mathrm{~g} / \mathrm{kg}$ body wt.를 3 주간 경구 투여하였다. 21 일째 투여 후 12 시간 금식시킨 뒤 22 일에도 각각의 시료 와 알코올을 경구 투여하였으며 알코올 투여 3시간 후에 모든 실험동물을 에테르 마취시켜 심장 채혈하였다. 채취 된 혈액은 $3000 \times \mathrm{g}, 4^{\circ} \mathrm{C}$ 에서 20 분간 원심 분리하여 혈청을 분리하였고, 시료 분석 시까지 $-70^{\circ} \mathrm{C}$ 에 보관하였으며, 알코 올, 아세트알데하이드, ALT, AST, $\gamma$-GTP, 중성지방, 총콜레 스테롤, $\mathrm{HDL}$-콜레스테롤 농도와 혈당 농도 측정에 사용되 었다. 또한 실험동물의 간조직은 phosphate buffered saline(PBS) 용액에 수차례 헹군 후 표면의 수분을 제거하여 칭량하였고, 효소활성도 측정, 지질 정량용으로 분리 수집 하여 액체질소에 급냉 시킨 후 시료 분석 시까지 $-70^{\circ} \mathrm{C}$ 에서 보관하였으며, 간조직 중성지방 및 콜레스테롤 농도 측정 에 사용되었다.

\section{혈청 알코올 농도 측정}

혈청 알코올 농도는 알코올 측정 kit(Roche, Hayward, CA, USA)를 이용하여 제조사의 매뉴얼에 따라 측정하였 다. 알코올 측정 $\mathrm{kit}$ 에 포함된 반응용액 $3 \mathrm{~mL}$ 에 혈청 0.1 $\mathrm{mL}$ 을 혼합하여 $20^{\circ} \mathrm{C}$ 에서 3 분간 incubation시킨 다음 340 $\mathrm{nm}$ 에서 흡광도를 측정(A1)하고, $\mathrm{ADH} 0.05 \mathrm{~mL}$ 를 넣은 뒤 $20^{\circ} \mathrm{C}$ 에서 5 분간 incubation한 뒤 $340 \mathrm{~nm}$ 에서 흡광도를 측정 (A2)하여 두 흡광도차를 아래의 계산식에 대입하여 혈중 알코올 농도를 측정하였다.

$$
\begin{aligned}
& \text { Concentration }=0.7259 / 3.6 \times \triangle \mathrm{A} \\
& \triangle \mathrm{A}=\text { sample }(\mathrm{A} 2-\mathrm{A} 1)-\text { blank }(\mathrm{A} 2-\mathrm{A} 1)
\end{aligned}
$$

\section{혈청 아세트알데하이드 측정}

혈청 아세트알데히드 농도는 아세트알데히드 측정 $\mathrm{kit}($ Roche)를 사용하여 측정하였다. 아세트알데하이드는 반응용액 $3 \mathrm{~mL}$ 에 혈청 $0.2 \mathrm{~mL}$ 을 혼합하여 $20^{\circ} \mathrm{C}$ 에서 3 분간 incubation시킨 다음 $340 \mathrm{~nm}$ 에서 흡광도를 측정(A1)하고, $\mathrm{ALDH} 0.05 \mathrm{~mL}$ 를 넣은 뒤 $20^{\circ} \mathrm{C}$ 에서 5 분간 incubation한 뒤 $340 \mathrm{~nm}$ 에서 흡광도를 측정(A2)하여 두 흡광도차를 아래 의 계산식에 대입하여 혈중 아세트알데하이드 농도를 측정 하였다.

$$
\begin{aligned}
& \text { Concentration }=0.7158 / 3.6 \times \triangle \mathrm{A} \\
& \triangle \mathrm{A}=\text { sample }(\mathrm{A} 2-\mathrm{A} 1)-\text { blank }(\mathrm{A} 2-\mathrm{A} 1)
\end{aligned}
$$

간기능 지표인 혈청 ALT, AST, $\gamma$-GTP 활성도 측정

$\mathrm{ALT}, \mathrm{AST}$ 및 $\gamma$-GTP 농도는 자동혈청분석기(Konelab
20XT, Thermo Electron, Louisville, CO, USA)를 사용하여 측정하였다.

\section{혈청 지질 및 혈당 농도 측정}

혈청 중성지방, 총콜레스테롤 및 high density lipoprotein (HDL)-콜레스테롤 농도와 혈당 농도는 자동혈청분석기 (Konelab 20XT, Thermo Electron, Louisville, CO, USA)를 사용하여 측정하였다.

\section{간조직 지질 농도 측정}

간조직 지질은 Folch 등(26)의 방법으로 추출하였다. 간 조직 $0.5 \mathrm{~g}$ 을 잘게 자른 후 $5 \mathrm{~mL}$ chloroform:methanol(2:1) 용액으로 균질화시켜 조직 지질을 추출하였다. 추출액은 Whatman 여과지(No. 2)로 걸러내고 질소 가스로 건조시킨 후 동일 추출용매 $1 \mathrm{~mL}$ 에 다시 녹였다. 이 중 중성지질과 총콜레스테롤 측정용으로 각각 $100 \mu \mathrm{L}$ 를 취하여 다시 질소 가스로 건조시키고 $5 \mathrm{~mL}$ 의 에탄올로 용해시킨 후, 측정 $\mathrm{kit}$ (아산제약 kit)를 이용하여 제조사의 매뉴얼에 따라 측정 하였다.

\section{통계처리}

실험의 모든 결과는 컴퓨터 통계 프로그램 중의 하나인 SPSS package program (SPSS Inc., Chicago, IL, USA)을 이용하여 산출되었다. 각 군간의 평균차이에 대한 유의성 검정은 one-way ANOVA(analysis of variance)를 실시하고 다군간의 차이는 Duncan's multiple range test에 의해 $\mathrm{p}<0.05$ 수준에서 사후검정을 실시하였으며, 그 결과를 Meant $\mathrm{SE}$ (standard error)로 표시하였다.

\section{결과 및 고찰}

\section{급성 알코올 투여에 의한 숙취해소 효능 검증}

혈중 알코올 및 아세트알데하이드 농도

일반적으로 알코올은 경구투여한 후 약 30 분 이내에 섭 취량의 60 90\%가 흡수되고 음주 후 60 120분 사이에 최고 치에 도달한다고 알려져 있다(27). 알코올 투여 후, 알코올 의 최고농도에 도달한 시간은 모든 실험군이 1 시간으로 나타났고, 1 시간 이후 서서히 감소하는 것으로 나타났다. 알코올 섭취 3 시간 후, 알코올대조군(ET)에 비해 헛개열매 열수추출물을 투여한 헛개열매군(ET-HWE)에서는 알코올 농도가 $19.1 \%$, 헛개열매추출액발효물을 투여한 헛개열매 발효군(ET-FHWE)에서는 $46.1 \%$ 정도의 유의적인 감소를 보였다(Fig. 1). 알코올 5시간의 혈중 알코올 농도는 헛개열 매군(ET-HWE), 헛개열매발효군(ET-FHWE) 모두 알코올 대조군(ET)보다 유의적으로 감소하여 정상수준으로 회복 되었다. 헛개열매의 혈중 알코올 농도 저하 효과는 이미 

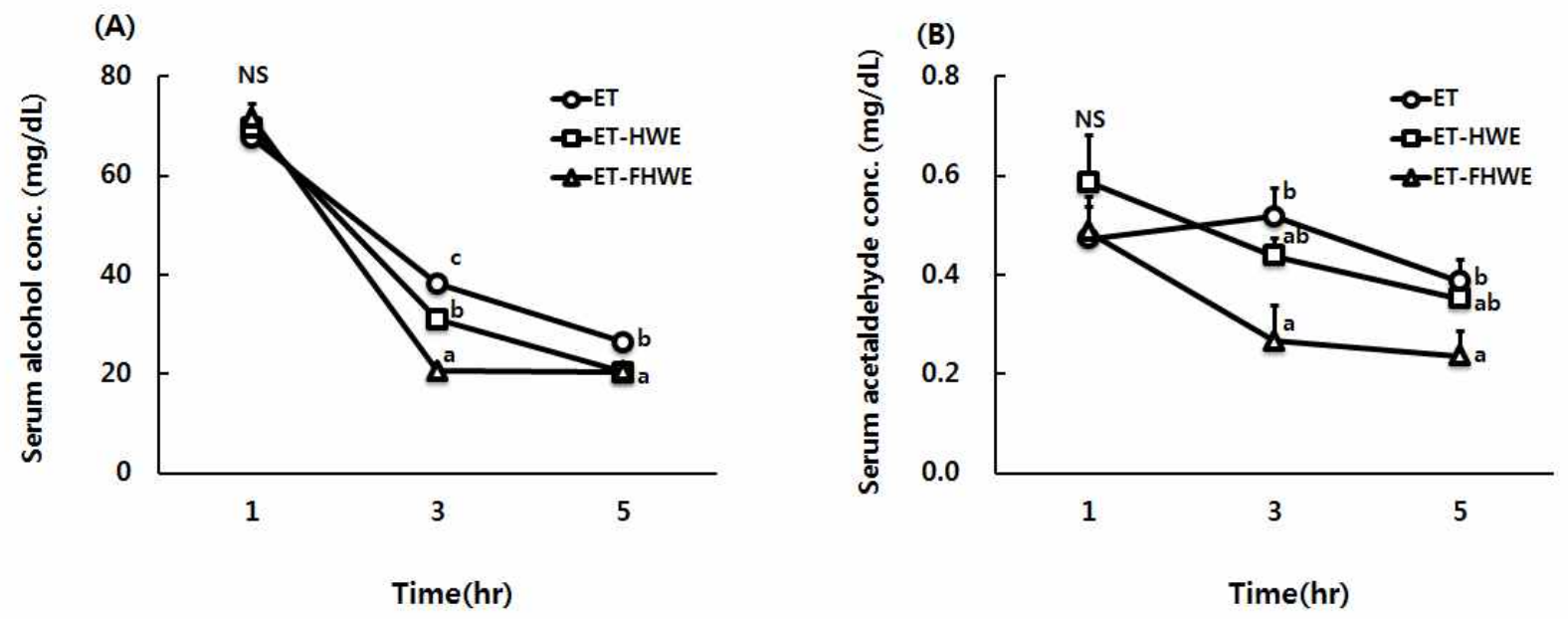

Fig. 1. Effect of the Fermented Hovenia dulcis Thunb fruit water extract on serum alcohol (A) and acetaldehyde (B) concentrations in rats given acute ethanol administratoin.

Data are Mean \pm SE. ${ }^{\text {abc }}$ Means not sharing a common letter are significantly different between groups at $p<0.05$. NS, not significant; NC, normal control; ET, ethanol; ET-HWE, ethanl+Hovenia dulcis Thunb fruit water extract; ET-FHWE, ethanol+Fermented Hovenia dulcis Thunb fruit water extract.

여러 차례 보고되었고(15-18), Kim 등(17)의 연구결과에 따르면 헛개열매 열수추출물 투여에 의해 $\mathrm{ADH}$ 와 $\mathrm{ALDH}$ 활성이 대조군에 비해 증가하는 것으로 보고되었다. 본 연 구결과에서도 헛개열매열수추출물은 혈중 알코올 농도를 감소시켰고, 헛개열매추출액발효물이 헛개열매열수추출 물보다 더욱 빠른 시간 안에 혈중 알코올 농도를 정상 수준 으로 회복시키는 것으로 나타나, 헛개열매열수추출물은 발 효에 의해 직간접적으로 $\mathrm{ADH}$ 수준이나 활성을 조절하는 것으로 사료된다.

알코올 섭취가 유해한 것은 알코올 자체보다 대사과정에 생성되는 중간 산물인 아세트알데하이드에 의한 영향이 크며(28), 아세트알데하이드가 과량일 경우에는 혈류를 통 하여 뇌와 다른 장기로 이동하여 유해한 영향을 미칠 뿐만 아니라 $\mathrm{ALDH}$ 활성도를 감소시키는 것으로 알려져 있다 (29).

본 실험을 통해 혈중 아세트알데하이드를 시간별로 측정 한 결과, 헛개열매군(ET-HWE), 헛개열매발효군(ET-FHWE) 은 모두 알코올 투여 1 시간 후에 최고 농도에 도달하였으며 이후 꾸준히 감소하는 것으로 관찰되었다. 반면, 알코올대 조군(ET)은 알코올 투여 3시간 후에 최고농도에 도달하는 것으로 나타났다. 알코올 투여 3 시간 후 혈 중 아세트알데하 이드 농도는 헛개열매군(ET-HWE)이 알코올대조군(ET)보 다 감소하는 경향을 보였고, 헛개열매발효군(ET-FHWE)은 알코올대조군(ET)보다 $48.7 \%$ 유의하게 감소하였다. 5 시간 후 혈중 아세트알데하이드 농도 또한 헛개열매군 (ET-HWE)이 알코올대조군(ET)보다 감소하는 경향을 보였 고, 헛개열매발효군(ET-FHWE)은 알코올대조군(ET)보다 $39 \%$ 정도 유의하게 감소하였다(Fig. 1). 이를 통해 헛개열매 추출액발효물은 헛개열매열수추출물보다 숙취의 원인 물
질인 아세트알데하이드를 더욱 신속하게 대사시켜 그 농도 를 감소시키는 것으로 나타나 알코올 섭취로 인해 나타나는 증상을 경감시킬 수 있을 것으로 예상된다.

\section{간기능 지표인 혈청 AST, ALT, $\gamma$-GTP 활성도 측정}

일반적으로 AST, ALT, $\gamma$-GTP는 간세포에 존재하는 효 소로 간조직이 손상되면 세포외로 다량 유출되어 혈액에 증가되어 간손상 지표로 이용되는 효소로, 알코올로 인한 간 손상 시에도 그 수치가 증가한다(30). 본 실험에서는 알코올 단회 투여 5시간 후 채취한 혈청을 분석한 결과, AST, ALT 및 $\gamma$-GTP는 군간 유의적인 차이가 나타나지 않았다(Table 1). 따라서 알코올의 단회 투여는 간 기능 관련 효소활성도에는 유의한 영향을 미치지 않는 것으로 사료되 며 이는 알코올의 단회 투여가 알코올대사 효소의 활성에 영향을 미치지 못한다는 보고와 일치하는 결과이다(31).

Table 1. Effect of the Fermented Hovenia dulcis Thunb fruit water extract on serum ALT, AST and $\gamma$-GTP activities in rats after 5 hours of acute ethanol administration

\begin{tabular}{lccc}
\hline & ALT (U/L) & AST (U/L) & $\gamma$-GTP (U/L) \\
\hline ET & $34.77 \pm 1.90^{\text {NS }}$ & $148.43 \pm 6.93^{\mathrm{NS}}$ & $5.52 \pm 0.36^{\mathrm{NS}}$ \\
ET-HWE & $34.97 \pm 0.93$ & $142.57 \pm 4.63$ & $4.23 \pm 0.49$ \\
ET-FHWE & $38.43 \pm 1.84$ & $160.64 \pm 9.19$ & $4.83 \pm 0.67$ \\
\hline
\end{tabular}

Data are Mean \pm SE. NS, not significant; ET, ethanol; ET-HWE, ethanl+Hovenia dulcis Thunb fruit water extract; ET-FHWE, ethanol+Fermented Hovenia dulcis Thunb fruit water extract.

만성 알코올 투여에 의한 간기능 개선 효능검증

혈중 알코올 및 아세트알데하이드 농도

21 일 동안 $40 \%$ 알코올 $5 \mathrm{~g} / \mathrm{kg}$ 을 투여하고, 22일째 알코올 
(A)

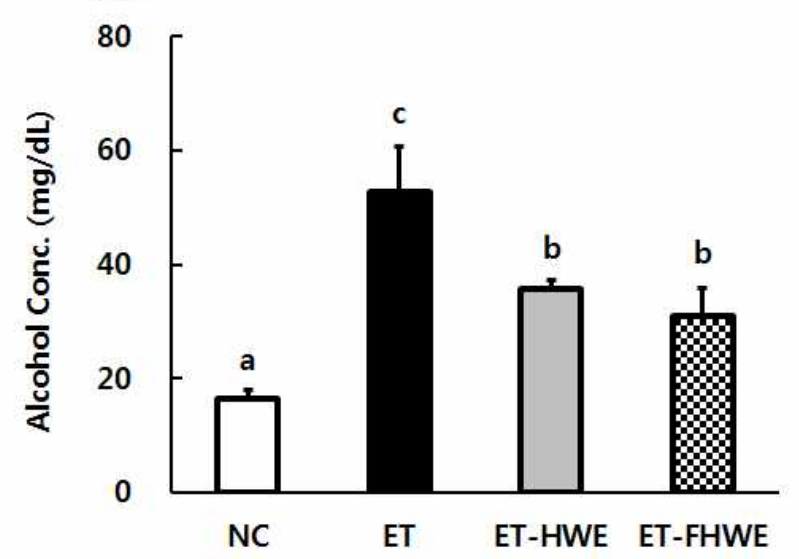

(B)

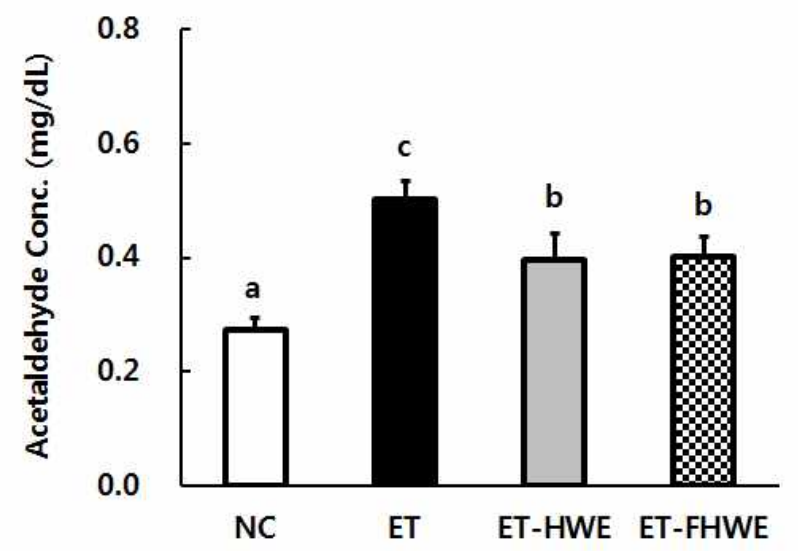

Fig. 2. Effect of the Fermented Hovenia dulcis Thunb fruit water extract on serum alcohol (A) and acetaldehyde (B) concentrations in rats administrated ethanol orally for 3 weeks.

Data are Mean \pm SE. ${ }^{\text {abc }}$ Means not sharing a common letter are significantly different between groups at p<0.05. NC, normal control; ET, ethanol; ET-HWE, ethanl+Hovenia dulcis Thunb fruit water extract; ET-FHWE, ethanol+Fermented Hovenia dulcis Thunb fruit water extract.

투여 3시간 뒤의 혈중 알코올 농도를 측정한 결과는 다음과 같다(Fig. 2). 알코올대조군(ET)의 혈중 알코올 농도는 $50.62 \mathrm{mg} / \mathrm{dL}$ 로 가장 높게 관찰되었으며 헛개열매군 (ET-HWE) 및 헛개열매발효군(ET-FHWE)의 혈중 알코올 농도는 각각 $35.85 \pm 1.43,30.96 \pm 4.97 \mathrm{mg} / \mathrm{dL}$ 로 알코올대조 군(ET)보다 혈중 알코올 농도가 현저히 감소한 것으로 나타 났다. 따라서 헛개열매열수추출물과 헛개열매추출액발효 물의 섭취는 알코올 대사를 빠르게 진행시켜 더욱 빠른 시간 안에 혈중 알코올 농도를 저하시키는 것으로 사료 된다.

만성적인 알코올 섭취 후, 혈중 아세트알데하이드 농도 를 측정한 결과, 알코올 농도와 유사하게 헛개열매군 (ET-HWE)과 헛개열매발효군(ET-FHWE)의 아세트알데하 이드 농도는 각각 $0.40 \pm 0.05 \mathrm{mg} / \mathrm{dL}, 0.40 \pm 0.03 \mathrm{mg} / \mathrm{dL}$ 로 나 타나 알코올대조군(ET) $(0.50 \pm 0.03 \mathrm{mg} / \mathrm{dL})$ 보다 혈중 아세 트알데하이드 농도가 현저하게 감소된 것으로 나타났다 (Fig. 2).

\section{간기능 지표인 혈청 AST, ALT, $\gamma$-GTP 활성도 측정}

급성 알코올 실험과 마찬가지로 3주간의 알코올 투여 결과에서도 AST, ALT 활성도는 실험군간 유의적인 차이가 나타나지 않았다. 반면 $\gamma$-GTP는 알코올대조군(ET)이 가장 높은 활성을 보여 만성적인 알코올 투여에 의해 $\gamma$-GTP의 활성이 증가한 것으로 관찰되었다(Table 2). $\gamma$-GTP는 $\gamma$ -glutamylpeptide를 가수분해함과 동시에 $\gamma$-glutamyl기와 다 른 아미노산이나 peptide의 전이 반응을 촉매하는 막결합 효소이고, 세포내의 glutathione의 분해와 합성에 관여한다 $(32,33)$. 정상인 간에서는 이 효소의 활성은 대단히 낮지만 여러 질환이 발생할 때 간에서의 활성은 증가되고 혈청에서
도 급격한 상승을 보인다(34). 알코올이나 약물로 인해 간장 애가 생기면 혈 중 $\gamma$-GTP가 증가하며, 특히 알코올에 민감 하게 반응하여 간이나 담도에 질환이 있으면 다른 효소보다 빨리 이상치를 보여 일반적으로 알코올에 의한 간 장애의 지표가 되며(35), $\gamma$-GTP와 지방간 정도는 양의 상관관계에 있어 흔히 지방간 수치로도 불린다. ALT, AST, ALP, 혈청 총단백 등 다른 간기능 검사는 정상이나 $\gamma$-GTP만이 고활성 을 보일 경우 알코올 섭취가 원인으로 해석되며 본 실험 결과에서도 AST, ALT는 군간 유의적인 차이가 없었으나 $\gamma$-GTP는 알코올대조군(ET)이 정상대조군보다 $28.65 \%$ 유 의적으로 상승한 것으로 나타났다.

한편 헛개열매 열수추출물은 알코올 섭취에 따른 $\gamma$-GTP 활성을 억제하는 것으로 보고되었는데(36), 본 실험을 통해 서도 알코올 투여에 의해 상승된 $\gamma$-GTP 활성도는 헛개열매 군(ET-HWE)과 헛개열매발효군(ET-FHWE)에서 각각 6.71 $\pm 0.21 \mathrm{U} / \mathrm{L}, 6.72 \pm 0.44 \mathrm{U} / \mathrm{L}$ 로 나타나 헛개열매열수추출물과 헛개열매추출액발효물은 알코올에 의해 상승된 $\gamma$-GTP 활

Table 2. Effect of the Fermented Hovenia dulcis Thunb fruit water extract on serum ALT, AST and $\gamma$-GTP activities in rats administrated ethanol orally for 3 weeks

\begin{tabular}{lccc}
\hline & ALT (U/L) & AST (U/L) & $\gamma$-GTP (U/L) \\
\hline NC & $36.50 \pm 2.14^{\text {NS }}$ & $118.64 \pm 6.92^{\mathrm{NS}}$ & $6.23 \pm 0.37^{\mathrm{a}}$ \\
ET & $40.47 \pm 2.69$ & $129.03 \pm 5.04$ & $8.02 \pm 0.24^{\mathrm{b}}$ \\
ET-HWE & $38.75 \pm 1.73$ & $111.38 \pm 8.84$ & $6.71 \pm 0.21^{\mathrm{a}}$ \\
ET-FHWE & $35.17 \pm 1.49$ & $121.77 \pm 11.37$ & $6.72 \pm 0.44^{\mathrm{a}}$ \\
\hline
\end{tabular}

Data are Mean \pm SE. ${ }^{\text {ab }}$ Means in the same column not sharing a common superscript are significantly different among groups at $\mathrm{p}<0.05$. NS, not significant; NC, normal control; ET, ethanol; ET-HWE, ethanl+Hovenia dulcis Thunb fruit water extract; ET-FHWE, ethanol+Fermented Hovenia dulcis Thunb fruit water extract. 
성을 각각 $16.3 \%, 16.1 \%$ 유의적으로 감소시키는 것으로 관찰되었다(Table 2).

\section{체중 변화}

알코올 섭취에 의한 체중 변화를 살펴 본 결과는 다음 Fig. 3과 같다. 알코올 섭취군들의 체중이 정상대조군보다 다소 감소하는 가운데 실험 종료일인 21 일째에는 알코올대 조군 $(\mathrm{ET})$ 이 비알코올투여군인 정상대조군 $(\mathrm{NC})$ 에 비해 $9.5 \%$ 유의적으로 체중이 감소하였다. 반면, 헛개열매군 (ET-HWE) 및 헛개열매발효군(ET-FHWE)의 체중은 알코 올대조군(ET)보다 각각 $7.2 \%, 4.5 \%$ 증가하는 경향을 보였 으며 군 간 식이섭취량의 차이는 나타나지 않았다. 따라서 헛개열매열수추출물 및 헛개열매추출액발효물은 알코올 섭취로 인한 체중 감소현상을 일부 회복시키는 것으로 사료 되며 이는 알코올 유도 만성 간손상 동물 모델에서 헛개나 무열매 열수추출물의 보충이 알코올 섭취에 따른 체중 감소 를 억제한다는 기존의 보고와도 일관성 있는 결과이다(36). 따라서 본 실험 결과를 통해서 헛개열매열수추출물과 헛개 열매추출액발효물은 알코올 섭취에 의한 체중 저하를 일부 개선시키는 것으로 확인되었다.

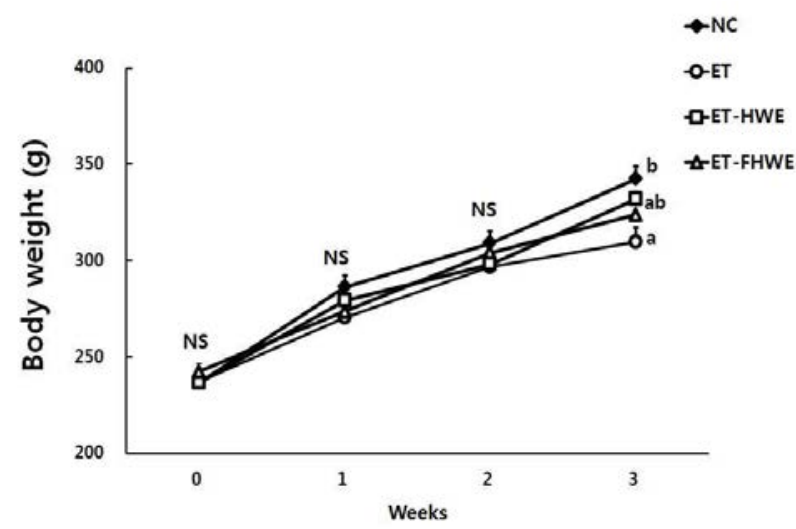

Fig. 3. Effect of the Fermented Hovenia dulcis Thunb fruit water extract on body weight changes in rats administrated ethanol orally for 3 weeks.

Data are Mean \pm SE. ${ }^{\text {ab }}$ Means not sharing a common letter are significantly different between groups at $\mathrm{p}<0.05$. NS, not significant; NC, normal control; ET, ethanol; ET-HWE, ethanl+Hovenia dulcis Thunb fruit water extract; ET-FHWE, ethanol+Fermented Hovenia dulcis Thunb fruit water extract.

\section{혈청 지질 함량}

만성적인 알코올 섭취는 세포내 체내 영양소 대사에 장 애를 초래하게 되며, 특히 말초 지방조직의 지질분해 증가, 지방산의 과잉생산, $\mathrm{NADH} / \mathrm{NAD}$ ratio 증가에 따른 지방산 산화의 감소 등으로 인해 혈청 및 간조직에서의 지질합성이 증가된다(13). Hong 등(14)의 연구결과에 따르면 헛개열매 열수추출물의 4주간 급여에서 $\mathrm{HDL}$-콜레스테롤 농도는 유 의적인 차이가 없었고, 혈청 총콜레스테롤 및 중성지방 농 도는 알코올대조군(ET)에 비해 유의적으로 감소하였다. 본 연구에서는 21 일간 알코올을 투여한 군들의 혈청 중성지방
농도는 정상대조군에 비해 유의적으로 증가한 반면, 헛개 열매추출액발효물의 투여는 혈청 중성지방 농도를 알코올 대조군(ET)보다 감소시키는 경향을 보였으며 혈청 총콜레 스테롤 농도와 $\mathrm{HDL}$-콜레스테롤 농도는 군간 유의적인 차 이가 나타나지 않았다(Fig. 4).

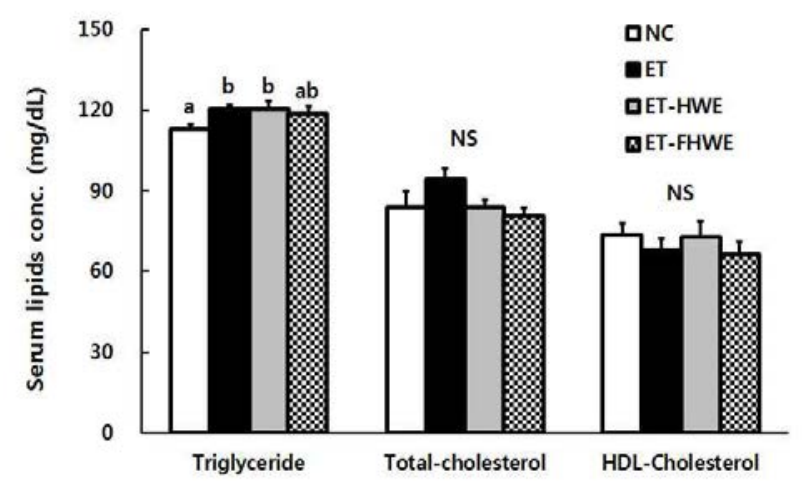

Fig. 4. Effect of the Fermented Hovenia dulcis Thunb fruit water extract on serum lipids concentration in rats administrated ethanol orally for 3 weeks.

Data are Mean \pm SE. ${ }^{a b}$ Means not sharing a common letter are significantly different between groups at p $<0.05$. NS, not significant; NC, normal control; ET, ethanol; ET-HWE, ethanl+Hovenia dulcis Thunb fruit water extract; ET-FHWE, ethanol+Fermented Hovenia dulcis Thunb fruit water extract.

\section{간조직 지질 함량}

3 주간의 알코올 섭취에 의해 지방간이 유발된 랫드의 간조직 지질 함량을 측정한 결과, 알코올대조군(ET)의 간조 직 중성지방 함량은 정상대조군에 비해 유의적으로 증가하 였다. 반면 헛개열매열수추출물 및 헛개열매추출액발효물 을 투여한 시험군들은 알코올대조군(ET)에 비해 간조직

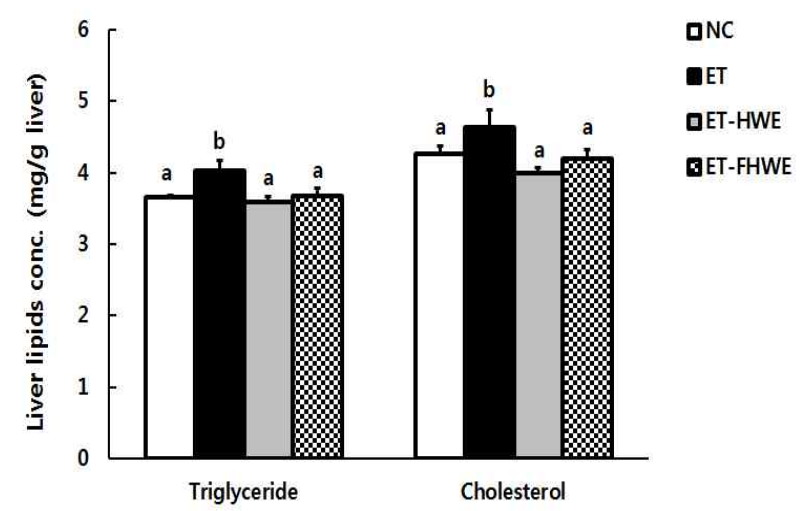

Fig. 5. Effect of the Fermented Hovenia dulcis Thunb fruit water extract on liver lipids concentration in rats administrated ethanol orally for 3 weeks.

$\mathrm{Mean} \pm \mathrm{SE}$. ${ }^{\mathrm{ab}}$ Means not sharing a common letter are significantly different between groups at $\mathrm{p}<0.05$. NC, normal control; ET, ethanol; ET-HWE, ethanl+Hovenia dulcis Thunb fruit water extract; ET-FHWE, ethanol+Fermented Hovenia dulcis Thunb fruit water extract. 
중성지방 함량이 유의적으로 감소하였고, 이는 정상대조군 의 간조직 중성지방 함량과 유사한 것으로 나타났다. 또한 간조직 콜레스테롤 함량도 헛개열매군(ET-HWE)과 헛개 열매발효군(ET-FHWE)에서 알코올대조군(ET)보다 유의 적으로 감소하였다(Fig. 5). 이를 통해 헛개열매열수추출물 과 헛개열매추출액발효물은 혈청 및 간 지질대사를 개선시 킴으로써 지방간으로 인한 간세포의 손상을 지연시키는 것으로 사료된다.

\section{공복혈당 함량}

일반적으로 간은 정상적인 혈당을 유지하기 위해 충분한 글리코겐을 보유하지만 알코올 섭취 시에는 알코올 산화로 인해 NADH/NAD ratio가 증가되고 이는 gluconeogenesis를 억제하여 저혈당을 유발시킨다고 보고되었다(37). 본 실험 을 통해서도 알코올의 섭취로 인해 알코올대조군(ET)의 혈당 농도는 $70.58 \pm 11.06 \mathrm{mg} / \mathrm{dL}$ 로 정상대조군보다 $41 \%$ 감소하였고, 헛개열매군(ET-HWE)도 정상대조군보다 혈 당 농도가 유의적으로 낮게 관찰되었다. 반면, 헛개열매추 출액발효물을 섭취한 헛개열매발효군(ET-FHWE)의 혈당 농도는 $114.87 \pm 11.33 \mathrm{mg} / \mathrm{dL}$ 로 알코올대조군(ET)보다 $62.74 \%$ 유의적으로 증가하였고, 정상대조군의 혈당 농도 와 거의 유사하게 나타나 헛개열매추출액발효물은 알코올 투여로 인해 저해될 수 있는 간의 당대사를 정상화시켜 정상적인 혈당 농도 유지에 기여하는 것으로 사료된다 (Fig. 6).

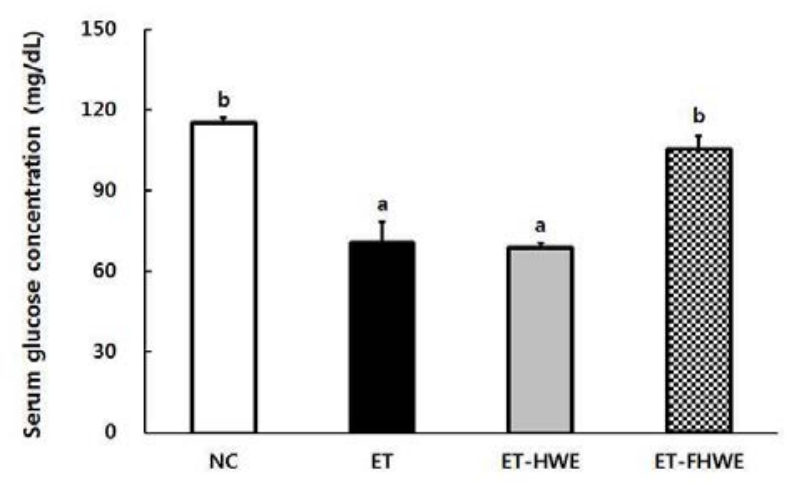

Fig. 6. Effect of the Fermented Hovenia dulcis Thunb fruit water extract on serum glucose concentration in rats administrated ethanol orally for 3 weeks.

Mean \pm SE. ${ }^{\text {bb }}$ Means not sharing a common letter are significantly different between groups at $\mathrm{p}<0.05$. NC, normal control; ET, ethanol; ET-HWE, ethanl + Hovenia dulcis Thunb fruit water extract; ET-FHWE, ethanol+Fermented Hovenia dulcis Thunb fruit water extract.

이상의 결과를 통해 헛개열매추출액발효물은 헛개열매 열수추출물의 우수한 간기능 개선 효능을 유지하면서 알코 올 및 아세트알데하이드 분해능은 더욱 증가시키는 것으로
나타나 이는 알코올분해 및 간기능 회복에 주요하게 작용하 는 유효성분인 dihydromyricetin(38)이 발효에 의해 증가되 었을 것으로 사료된다. 또한 헛개열매추출액발효물은 만성 적인 알코올 투여에 의해 발생하는 혈중 지질 증가나 혈당 감소는 헛개열매열수추출물보다 더욱 효과적으로 개선시 키는 것으로 나타나 발효에 의한 기능성 향상이 입증되었 다. 따라서 헛개열매추출액발효물은 만성 알코올 섭취에 의한 심한 체중 감소를 억제하며 숙취해소 및 알코올성 간손상 예방/치료 물질로서 헛개열매열수추출물보다 더욱 우수한 물질로 활용될 것으로 기대된다.

\section{요 약}

발효에 의한 헛개열매의 기능성 상승 정도를 검토하고 자, 헛개열매열수추출물을 발효시킨 후 급성 및 만성 알코 올 투여 간손상 동물모델을 통하여 체중감량 억제, 알코올 분해 및 간기능 개선 효능을 검증하였다. 급성 알코올 투여 동물모델에서 헛개열매발효군(ET-FHWE)은 알코올대조 군(ET)에 비하여 혈청 알코올 농도가 유의적으로 감소되었 고, 특히 알코올 투여 3 시간 후의 알코올 농도는 헛개열매추 출액발효물에 의해 $46.1 \%$, 헛개열매열수추출물에 의해 $19.1 \%$ 감소된 것으로 나타났다. 또한 알코올 투여에 의해 증가된 혈청 아세트알데하이드 농도는 헛개열매추출액발 효물에 의해 알코올 투여 3 시간 후에는 $48.7 \%, 5$ 시간 후에 는 $39 \%$ 로 알코올대조군(ET)보다 유의적으로 감소하였고, 이는 헛개열매열수추출물은 발효에 의해 알코올 및 아세트 알데하이드 분해능이 증가하는 것으로 사료되었다. 만성 알코올 투여 간손상 동물모델 실험에서 알코올 투여에 의해 상승된 혈청 알코올 농도는 헛개열매열수추출물과 헛개열 매추출액발효물 투여에 의해 각각 $31 \%, 41 \%$ 유의적으로 감소하였다. 혈청 아세트알데하이드 농도와 $\gamma-\mathrm{GTP}$ 활성도 는 헛개열매열수추출물과 헛개열매추출액발효물 투여에 의해 알코올대조군(ET)보다 유의적으로 감소되었으며, 장 기간 알코올 투여에 의한 체중 감소 억제 및 간조직 지질 수준의 유의적 감소를 나타내었다. 또한 헛개열매추출액발 효물은 장기간의 알코올 투여로 인해 감소된 혈당을 유의적 으로 증가시키는 것으로 나타났다. 본 연구 결과, 급성 알코 올 투여 동물모델에서 헛개열매열수추출물은 발효에 의해 알코올 및 아세트알데하이드 분해능이 증진되었고, 만성 알코올 투여 모델을 통한 실험에서는 발효에 의해 헛개열매 의 간기능 개선효능이 유지됨과 동시에 일부 효능(혈청 지 질 및 혈당 수준 개선능)은 증가하는 것으로 나타났다. 따라 서 헛개열매추출액발효물은 급성 및 만성 알코올성 간손상 억제에 있어서 헛개열매열수추출물보다 더욱 강력한 기능 성 물질로 활용될 수 있을 것으로 기대된다. 
감사의 글

본 연구는 2011학년도 경북대학교 융 - 복합연구 지원 프로그램과 대구테크노파크 기술인프라연계 연구개발사 업의 지원을 받아 연구되었으며 이에 감사드립니다.

\section{References}

1. Bunout D (1999) Nutritional and metabolic effects of alcoholism: their relationship with alcoholic liver disease. Nutrition, 15, 583-589

2. Baan R, Straif K, Grosse Y, Secretan B, El Ghissassi F, Bouvard V, Altieri A, Cogliano V (2007) Carcinogenicity of alcoholic beverages. Lancet Oncology, 8, 292-293

3. Corrao G, Rubbiati L, Bagnardi V, Zambon A, Poikolainen K (2000) Alcohol and coronary heart disease: A meta-analysis. Addiction, 95, 1505-1523

4. Baliunas DO, Taylor BJ Irving H, Roerecke M, Patra J, Mohapatra S, Rehm J (2009) Alcohol as a risk factor for type 2 diabetes: A systematic review and metaanalysis. Diabetes Care, 32, 2123-2132

5. Shelmet JJ, Reichard GA, Skutches CL, Hoeldtke RD, Owen OE, Boden G (1988) Ethanol causes acute inhibition of carbohydrate, fat, and protein oxidation and insulin resistance. J Clin Invest, 81, 1137-1145

6. Taylor B, Irving HM, Baliunas D, Roerecke M, Patra J, Mohapatra S, Rehm J (2009) Alcohol and hypertension: Gender differences in dose-response relationships determined through systematic review and meta-analysis. Addiction, 104, 1981-1990

7. Rehm J, Rehn N, Room R, Monteiro M, Gmel G, Jernigan D, Frick U (2003) The global distribution of average volume of alcohol consumption and patterns of drinking. Eur Addict Res, 9, 147-156

8. Chenet L, Britton A, Kalediene R, Petrauskiene J (2001) Daily variations in deaths in Lithuania: The possible contribution of binge drinking. Int J Epidemiol, 30, 743-748

9. Leon DA, Chenet L, Shkolnikov VM, Zakharov S, Shapiro J, Rakhmanova G, Vassin S, McKee M (1997) Huge variation in Russian mortality rates 1984-94: artefact, alcohol, or what? Lancet, 350, 383-388

10. Kessler RC, Crum RM, Warner LA, Nelson CB, Schulenberg J, Anthony JC (1997) Lifetime co-occurrence of DSM-III-R alcohol abuse and dependence with other psychiatric disorders in the National Comorbidity Survey.
Arch Gen Psychiatry, 54, 313-321

11. Samokhvalov AV, Irving H, Mohapatra S, Rehm J (2010) Alcohol consumption, unprovoked seizures and epilepsy: A systematic review and meta-analysis. Epilepsia, 51, 1177-1184

12. Lieber CS, DeCarli LM (1970) Hepatic microsomal ethanol oxidizing system: in vitro characteristics and adaptive properties in vivo. J Biol Chem, 245, 2505-2512

13. Lieber CS (1994) Alcohol and the liver. Gastroenterology, 106, 1085-1105

14. Hong YL, Kim MH, Ahn C, Lee HY, Kim JD (2000) Studies on the biological activities of the extracts from hovenia dulcis Thumb. J Agr Sci, 11, 1-11

15. Okuma $Y$, Ishikawa $H$, Ito $Y$, Hayashi $Y$, Endo A, Watanabe T (1993) Effect of extracts from Hovenia dulcis Thunb on alcohol concentration in rat and men administerd alcohol. J Jpn Soc Nutr Food Sci, 48, 167-172

16. Na CS, Chung NC, Yang KH, Kim SH, Chung HS, Dong MS (2004) Hepatoprotective and blood alcohol lowering effects of fruit peduncle extract of Hovenia dulcis var. korean in the in vitro and in vivo animal models. Yakhak Hoeji, 48, 34-40

17. Kim MH, Chung YT, Lee JH, Park YS, Shin MK, Kim HS, Kim DH, Lee HY (2000) Hepatic detoxification activity and reduction of serum alcohol concentration of Hovenia dulcis THUNB from Korea and China. Korean J Medicinal Crop Sci, 8, 225-233

18. Ji Y, Li J, Yang P (2001) Effects of fruits of Hovenia dulcis Thunb on acute alcohol toxicity in mice. Zhong Yao Cai, 24, 126-128

19. Kim HT, Kim DD, Ku SK, Kim JW, Lim MK, Oh TH, Lee KW (2011) Therapeutic Effects of Hovenia Dulcis Thunb Extract on CCl4 Induced Liver and Kidney Damage in Rats. J Vet Clin, 28, 20-7

20. Kim SM, Kang SH, Ma KY, Kim JH (2006) A study on the extraction and efficacy of bioactive compound from Hovenia dulcis. Korean J Biotechnol Bioeg, 21, 11-15

21. Na CS, Yoon SY, Kim JB, Na DS, Dong MS, Lee MY, Hong CY (2013) Anti-fatigue activity of Hoveniadulcis on a swimming mouse model through the inhibition of stress hormone expression and antioxidation. Am J Chin Med, 41, 945-955

22. Kim OK (2001) Protective effects of extracts of Hovenia dulcis Thunb on hepatotoxocity in carbon tetrachloride intoxicated rats. J Korean Soc Food Sci Nutr, 30, $1260-1265$ 
23. Hase K, Ohsugi M, Xiong Q, Basnet P, Kadota S, Namba $T$ (1997) Hepatoprotective effect of Hoveniadulcis THUNB. on experimental liver injuries induced by carbon tetrachloride or D-galactosamine/lipopolysaccharide. Biol Pharm Bull, 20, 381-385

24. Kim JS, Na CS, Eun JB (2005) Effect of Hovenia dulcis Thunb extract on the hyperglycemic mice induced with streptozotocin. J Korean Soc Food Sci Nutr, 34, 632-637

25. Lee YA, Chae HJ, Moon HY (2005) Effect of Hoveina dulcia Thunb. var. koreana Nakai fruit extract on glucose, lipid metabolism and antioxidant activity in streptozotocininduced diabetic rats. J Exp Biomed Sci, 11, 533-538

26. Folch J, Lees M, Sloane Stanley GH (1957) A simple method for the isolation and purification of total lipides from animal tissues. J Biol Chem. 226, 497-509

27. Shumate RP, Crowther RF, Zarafshan M (1967) A study of the metabolism rates of alcohol in the human body. J Forensic Med, 14, 83-100

28. Lieber CS (1973) Liver adaptation and injury in alcoholism. N Engl J Med, 288-356

29. Swift R, Davidson D (1998) Alcohol hangover: mechanisms and mediators. Alcohol Health Res World, 22, 54-60

30. Zimmerman HJ, Seeff LB (1970) Enzymes in hepatic disease. In: Diagnostic Enzymology, Goodly EL (Editor), Lea \& Febiger, PA, USA, p 1-38
31. Park EM, Ye EJ, Kim SJ, Choi HI, Bae MJ (2006) Eliminatory Effect of Health Drink Containing Hovenia Dulcis Thumb Extract on Ethaol-Induced Hangover in Rats. Korean J Food Culture, 21, 71-75

32. Tate SS, Meister A (1971) Gamma-glutamyl transpeptidase: catalytic, structural and functional aspects. Mol Cell Biochem, 39, 357-368

33. Rosalki SB, Rau D (1972) Serum-glutamyl transpeptidase activity in alcoholism. Clin Chim Acta, 39, 41-47

34. Boone DJ, Tietz NW, Weinstock A (1977) Siginificance of gamma-glutamyl transpeptidase(GGT) activity measurments in alcohol-induced hepatic injury. Ann Clin Lab Sci, 7, 25-28

35. Friedman SL (1990) Acetaldehyde and alcoholic fibrogenesis. Fuel to the fire, but not the spark. Hepatology, 12, 609-612

36. Kim YS, Park JY, Kwon YB, Lim DW, Song MK, Choi HY, Kim HC (2013) Hepatoprotective Effects of Hovenia dulcis Extract on Acute and Chronic Liver Injuries induced by Alcohol and Carbon Tetrachloride. Kor J Herbology, 28, 25-32

37. Lieber CS (1997) Ethanol metabolism, cirrhosis and alcoholism. Clin Chim Acta, 257, 59-84

38. Shen Y, Lindemeyer AK, Gonzalez C, Shao XM, Spigelman I, Olsen RW, Liang J (2012) Dihydromyricetin as a novelanti-alcohol intoxication medication. $\mathbf{J}$ Neurosci, 32, 390-401

(접수 2014년 2월 19일 수정 2014년 4월 21일 채택 2014년 4월 28일) 